\title{
Sex on the Desk, Coke in the Toilet, Bribery and Corruption on the Streets. An Investigation of Spiral as a Representation of Contemporary Policing
}

\author{
Dr Martin King ${ }^{1}$, and Ian Cummins ${ }^{2}$ \\ ${ }^{1}$ Manchester Metropolitan University, UK \\ ${ }^{2}$ University of Salford, UK
}

\begin{abstract}
Policing is widely recognised as one of the most stressful occupations. Numerous studies have explored the ways in which stress impacts on the personal and professional lives of officers. Using this literature as context, the paper explores the way in which representations of policing in film and TV have changed to reflect this issue, to the point where the predominant mode of representation is the dysfunctional officer broken by the job, while retaining key elements of traditional cop culture. In recent years UK audiences have embraced the dystopian pleasures of Nordic and Euro Noir. Many of these texts are characterized by a blurring of boundaries between police officers and those they seek to bring to justice, close relationships between police officers and criminal entrepreneurs and bribery and corruption at work in the legal system. There is a darkness at work here, both in terms of themes explored and the dysfunctional lives of the main players.

Using the research approach of bricolage, the paper will examine the contemporary French police drama Spiral, set in both the splendor and squalor of Paris, as an illustration of the shift in representations of policing and consider the reasons for and impact of this shift.
\end{abstract}

Key words: Policing; Stress; Film and TV; Representation; Spiral

\section{Introduction}

The Criminal Justice System is a part of society that is both familiar and hidden. It is familiar in that a large part of daily news and television drama is devoted to it (Carrabine, 2008; Jewkes, 2011). It is hidden in the sense that the majority of the population have little, if any, direct contact with the Criminal Justice System, meaning that the media may be a major force in shaping their views on crime and policing (Carrabine, 2008). As Reiner (2000) notes, the debate about the relationship between the media, policing, and crime has been a key feature of wider societal concerns about crime since the establishment of the modern police force. He outlines the recurring themes in post-war debates in this field. For Conservatives there has been an ongoing concern that the media is criminongenic, as it serves to undermine traditional institutions, including the police. From the viewpoint of radical criminology, the impact of the media is two-fold: it exaggerates legitimate concerns about crime and emphasises the bureaucratic and other restrictions under which the police operate (Reiner, 2000). This is seen as undermining due process and legitimatising what can be termed a 'maverick' approach to policing. An early example of this can be seen in Clint Eastwood's Dirty Harry movies (Siegel, 1971) where Harry Callaghan acts as a one-man law enforcement system outside of the formal legal process, a process portrayed as corrupt, inefficient, and concerned with offenders' rights rather than protecting victims. From a policing perspective, Reiner (2000) argues that film and TV drama creates a simplistic narrative of crime solving that is almost completely divorced from the reality of modern police work, a finding consistent with more recent work by Cummins et al. (2014).

In popular culture the dominant portrayal of police and policing is one of heightened drama with the investigation of serious crimes, particularly sexual crimes, rampant serial killers, and murderous assaults by strangers as the staple diet of TV drama.. The media, it can be argued, has a key role to play in the construction of knowledge of crime and policing. Policing has been ranked amongst the five most stressful occupations (Violanti, 1996) and contemporary representations of policing often contain storylines which document the 
impact of investigating violent crime. This has, in fact, become a key theme of the modern police procedural drama. Representations of the police officer on a continuum ranging from 'married to the job' to 'broken by the job' has a history dating back to the emergence of the private investigator in the Hollywood film noir era of the 1940s (Clarke, 2005). This paper will explore this issue, tracing the development of the police procedural drama on TV and the changing representations of policing. It is worth, though, first exploring the issues of occupational culture and policing and stress which feed into such representations.

\section{Policing and Occupational Culture}

The term 'cop culture' can be interpreted as a label for a form of hegemonic masculinity (Hearn, 2004) found in police settings. The major themes here would be: an emphasis on action as a solution to problems; a strong sense of group identity and hyper-masculinity manifesting itself in a series of misogynistic and racist attitudes. In this schema, the police are hard-bitten, cynical and need to be aggressive to deal with the dangers that they face on a day to day basis. Reiner (2000) links the development of these cultural attitudes to the demands of police work itself rather than arising out of the wider society. Goldsmith (1990) suggests that these cultural attitudes are part of a functional response to the demands of the post. Waddington's (1999) work on police sub-culture is important here. Waddington (1999) concurs with the themes outlined by Reiner (2000) emphasising the us/them division and in-group isolation inherent in the sub-culture. Waddington (1999) argues, however, that police sub-culture is more complex than just a set of shared values; it can be seen as a set of attitudinal variables seeking to explain police behaviour and as a construct that pulls together a broad spectrum of thought or practice. It is, Waddington (1999) argues, a bridging concept between what police officers may say and do in the canteen (canteen culture) and how they may act in public.

Two elements of Waddington's (1999) exploration of police sub-culture are particularly pertinent to changing representations of policing over the decades and link directly to notions of police work as a stressful occupation. One is the conceptualisation of policing as 'dirty work' (Hughes, 1962). 'The police act in ways that would otherwise be exceptional, exceptionable or illegal' (Waddington, 1999:299), violating privacy, often using force, and this is key in relation to boundaries and the ways in which boundaries can be blurred. Glorifying violence and acting within the rules of hegemonic masculinity (Hearn, 2004) creates an image of the heroic figure. Linked to this is the occupational self-image of crime-fighter. A review of evidence by Morris and Heal (1981) concluded that the police have little impact on crime rates and spend little time on crime-related tasks. Waddington (1999) concludes his appreciation of cop culture by identifying the fragility of police culture and the marginal position of the police in wider society. These are issues which have come to the fore in more recent representations of policing and this situation often links directly to the stresses of the job, and the inherent contradiction between the police officer's self-image and the demands of the job in reality.

\section{Policing and Stress}

The policing environment is inherently stressful. Police officers come face a wide range of society's most intractable problems on a daily basis (Kelly, 2005).

A series of studies (Malasch, 1982; Violanti, 1996; Hackett and Violanti, 2003) emphasise that being a police officer can put mental and physical health at some risk. As Kelly (2005) notes, very little, if any, attention is paid to mental health issues in police training. Cummins and Jones (2010) argue that any police training in mental health awareness has to include a forum where officers can explore their own mental well-being. Part of the reason for this being the high level of need they identified, but, also, the fact that officers' greater understanding of their own mental health may improve working relationships with service- users. The emotional damage that policing can cause is related to the operational environment. As Weisinger (1985) states, officers on duty need to suppress emotions rather than express emotions. There is a well-established police culture of socialising with work colleagues, usually involving alcohol. This has inherent dangers, one of which is that this serves to isolate and alienate officers from their friends and families. In addition, police culture encourages the 
belief that officers are somehow immune to these pressures (Reiner, 2000). As Kirschmann (2000) notes, police officers do not seek help because of a mixture of pride and fear. The nature of the work means that officers can become alienated from the wider community, including their own families. The result is that they come to rely on the 'police family' which struggles to acknowledge that any difficulties exist in the first place. This was another key theme of the recent study conducted with retired officers (Cummins et al., 2014).

\section{Methods}

The use of bricolage to analyse texts, what Bentley (2005) has conceptualized particularly the recent emergence of Euro Noir and Nordic Noir as a post-structuralist approach in his study of 1990s' British fiction, was seen by the authors as highly relevant and appropriate. A textual analysis approach using a search for specific language, phrases and signs and signifiers was devised, based on a framework suggested by Fairclough (1995), McKee (2003) and van Dijk (1993), and was applied to the French police drama Spiral (Clert and Sainderichin, 2005-present), a good example of dystopian spectacle (Bolton, 2005) and a reflection of the impact of the job on individual police officers.

\section{Cops on UK TV}

UK audiences' enjoyment of the dystopian spectacle (Bolton, 2005) of Nordic and Euro Noir (Forshaw, 2014) is in sharp contrast to the first popular police procedural on UK TV, Dixon of Dock Green (Willis, 19551976). Dixon was 'a straight=thinking man with all the values of a boy scout' (Clarke, 2005:44) and the programme reflected a post-war consensus model of policing in an early-evening family viewing slot. However, on a 50 year journey to Spiral (Clert and Sainderichin, 2005-present) UK viewers saw the development of gritty realism (Z-Cars [Kennedy, Martin and Prior, 1962-1978]) in an inner city setting, the beginnings of a reflection of malpractice and police misconduct (The Sweeney [Kennedy, Martin, 1975-78]) and the emergence of police procedural as soap opera with the private lives of the officers as plot development (The Bill [McQueen, 19842010]). The 1990s brought Between The Lines (Wilsher, 1992-94) blurring the boundaries between policing and criminality and exploring the impact of that on individual officers, what Brunsdon (1998:235) calls 'grubby realism'. The noughties saw an escalation of 'grubby realism' as UK audiences embraced US series like The Wire (Simon, 2002-2004), taking the representation of the stressed-out dysfunctional officer to another level and paving the way for such representations in Nordic Noir (Wallander [Mankell, 2005-13]; The Killing [Sud, 201114]; The Bridge [Reid et al., 2013-14] and Euro Noir. Enter Spiral [Cleft and Sainderichin, 2005-present]).

\section{Spiral (Engrenages)}

According to Barry Forshaw (2014), Spiral (Clert and Sainderichin, 2005-present) represented a French response to popular Danish drama The Killing (Sud, 2011-14) and is 'a foreign detective series which treats its audience with intelligence and offers genuine texture and complexity' (Forshaw, 2014:78-9). First shown in France in 2005, it appeared in the UK in the summer of 2006 as BBC Four's first French-language drama series and audiences have grown from an initial 200,000. Series six is now in production. At the centre of Spiral (Clert and Sainderichin, 2005-present) is police captain Laure Berthaud, her physical appearance intertextually linked to Terminator's (Cameron, 1984) Sarah Connor, 'uninterested in the conventional feminine virtues, driving herself and the team with unsparing energy' (Forshaw, 2014:79). Her addiction to hegemonic cop culture (Waddington, 199; Hearn, 2004) and her broken-by-the stresses of the job behaviours, make her a perfect example of the way in which this has become the standard representation of the TV cop. Berthaud's police 'family' consists of lieutenants Gilles 'Gilou' Escoffier and Frederic 'Tin Tin' Fromentin and their relationships are central to Spiral (Clert and Sainderichin, 2005-present). Spiral (Clert and Sainderichin, 2005-present) goes beyond the standard representation of malpractice and corruption in policing and extends this to the work of the judiciary; the other three central characters are clever, corrupt and cynical lawyer Josephine Karlsson ,Judge Francois Roban, an investigating magistrate obsessed with his independence and unafraid to bend the rules when necessary and,in contrast, lawyer Pierre Clément struggles to maintain professional integrity in the face of 
interpersonal entanglements, temptations and an increasingly corrupt environment.Set in both the splendour and squalor of Paris Spiral (Clert and Sainderichin, 2005-present) is a dark, dysfunctional text and the actions of the characters and twists of plot represent a dystopian spectacle (Bolton, 2005) for the audience in a world where lies, corruption and unhappy personal relationships are never far away.

Series one provides the template for subsequent series, opening with the discovery of a body, in this case a women in a skip, and continuing by weaving together a number of interrelated plots in a dystopian tragedy. The murder of a baby, political intrigue, drugs and prostitution all feature in a storyline which links an old friend of lawyer Pierre Clément to the death of a prostitute and to an investigation into a prostitution ring. At one point Cléments loyalty to his friend lends him to try and retrieve an incriminating document from Judge Roban's office, an illustration that the representative of integrity in the series can also be led astray. Meanwhile the audience is introduced to Josephine Karlsson's ruthless and ambitious approach to her work as she takes on the dead baby case because of its media potential. Other key themes are also on display here. The 'broken-by-thejob off the rails' cop in Series one is Gilou, who is keeping company with a prostitute and has developed a cocaine habit. She organises his supply via the leader of the prostitution ring. In episode three of the series we see him snorting coke in the toilet of the police station, removing coke from a suspect and attempting to keep for his use and , at the end of the episode, in the prostitute's flat being given 'free' coke and having his debt written off in return for providing warnings around the investigation of the 'Romanian whore business'.

Throughout Spiral (Clert and Sainderichin, 2005-present) the close friendship, as part of the 'police family', between Laure Berthaud and Gilou is prominent, as they go through a number of dysfunctional relationships incompatible with the job, a key theme of cop drama since the 1970s (Leishman and Mason, 2003). In episode three Berthaud realises Gilou is 'back on it' and Berthaud and Tin Tin, 'the family', close ranks to protect him; similarly in a later series, when Tin Tin's marriage falls apart, another cop drama staple, the 'family' come together to support him.

The same episode sees Laure and Pierre Clément in a ‘your place or mine?' scenario following an incident in his office and Berthaud's casual approach to sex and inability to maintain relationships is another key theme of Spiral (Clert and Sainderichin, 2005-present). Later,in series three, she has sex on the desk with Vincent Brémant, director of the rival Criminal Brigade, in his office, initially to distract him so that Tin Tin and Gilou can retrieve a piece of incriminating evidence. This eventually develops into a full blown relationship but she is 'dumped' by him in episode nine of the series, where the rivalry between the squads and the importance of their triumph at the expense of justice is well illustrated.

Series three also features a storyline around local government corruption which sees Judge Roban's brother implicated in the case. Roban is another character illustrating the 'married to the job' model. As well as his distant relationship with his ailing mother and corrupt brother, the series also sees the unfolding of a tragic subplot around Roban taking on a long-lost lover's son as an intern who becomes embroiled in the local government corruption and eventually commits suicide.

The main plot of series three focuses on Berthaud's obsession with a serial killer at the expense of health and relationships, similar in many ways to the central characters in much of Nordic Noir (Murphy, 2010). Her obsession with the case which revolves around attacks on women and carving up their bodies, leads to a finale where she is alone with and shoots the killer, even though he is putting down the knife he is holding. When Brémont finally arrives she repeats 'I couldn't do otherwise' and she is led away by her 'family' Tin Tin and Gilou, knowing she will be under investigation.

Series two, in particular, provides a good illustration of the light and shade of Paris which forms the backdrop to Spiral (Clert and Sainderichin, 2005-present).Shots of affluent central Paris are set against images of gang wars in the suburbs which forms the basis of the plot; the Audis, BMWs and Porsches of the criminals contrasted with the Police Renaults, and an ending which contrasts the wide open spaces of Paris (and Spain, where the squad follow the drug gang) with the enclosed space of a police cell where there is a brother on brother murder redolent of a Shakespearean tragedy. 


\section{Conclusion}

The portrayal of police officers on screen has undergone a huge transformation. This paper has traced this change in representation with reference to the emergent literature on police culture and stress in the period discussed. The text subject to analysis by the authors represent a shift along a continuum where (Ferrell et al.'s (2008) spectacle or carnival of crime now includes the dystopian pleasure of seeing police officers' lives disintegrate before the eyes of the audience (Bolton, 2005). The awful events that are being investigated seem to have ensured that the police have lost any moral sense that they may have once had. The importance of and power and impact of representation has been well documented (Hall, 1987; Dyer, 2002). If then, as Reiner (2000) suggests, representations of policing in the media has an impact both on public perceptions and the development of policing, the predominance of the 'broken by the job' representations discussed here have a potential impact on the audience, police officers and policy makers. There is no denying the popularity of such representations with 21 st century audiences and the predominance of these dystopian pleasures (Bolton, 2005) in modern day cop shows. In addition, recent work with retired police officers (Cummins et al., 2014) suggests that there is some correlation between the representation of the stresses of policing and the experiences of retired officers. Further study in both of these areas would seem to be an imperative in examining the relationship between representations of and the realities of policing and stress.

\section{References}

[1] Bentley, N. (ed) [2005] British Fiction of the 1990s, London: Routledge.

[2] Bolton, Z. (2005) 'Entertainment as dystopia: Film Noir, Melodrama and Mildred Pierce', Crime culture, Spring,

[3] http:11www.crimeculture.com/Contents/Collforpapers.html. (accessed 17/07/2014).

[4] Brunsdon, C. (1998) 'Structure of Anxiety: recent British television crime fiction', Screen, 39 (3) Autumn, 223-245. http://dx.doi.org/10.1093/screen/39.3.223

[5] Cameron, J. (Director) [1984] The Terminator, Orion.

[6] Carrabine, E. (2008) Crime, Culture and the Media, Cambridge: Polity Press.

[7] Clarke, J. (2005) 'Crime and Social Orders: Interrogating the Detective Story' in J. Muncie and E. McCoughlin (eds) The Problem of Crime, London: Sage, 65-100.

[8] Clert, A. and Sainderichin, G.P. (Creators) [2005-present] Spiral, Canal/BBC Four.

[9] Cummins, I., Foley, M. and King, M. (2014) '... "And after the Break": police officers' views of TV crime drama', Policing: A Journal of Policing and Practice, 8(2), $205-211$.

[10] Dyer, R. (2003) The Matter of Images: essays on representation, London: Routledge.

[11] Fairclough, N. (1995) Media Discourse, London: Hodder.

[12] Foreshaw, B. (2014) Euro Noir, Harpenden: Oldcastle Books Ltd.

[13] Ferrell, J. Hayward, K. and Young, J. (2008) Cultural Criminology: An Invitation, London: Sage.

[14] Goldsmith, A. (1990), 'Taking Police Culture Seriously: Police Discretion and the Limits of Law', Policing and Society, 1, 91-114. http://dx.doi.org/10.1080/10439463.1990.9964608

[15] Hackett, D.P and Violanti, J. M. (2003): Police Suicide: Tactics for Prevention, Springfield IL: Charles C. Thomas.

[16] Hall, S. (ed) (1997) Representations; cultural representations and signifying practices, London: Routledge.

[17] Hearn, J. (2004) 'From Hegemonic Masculinity to the hegemony of men', Feminist Theory, 5(1), 49 - 72. http://dx.doi.org/10.1177/1464700104040813

[18] Hughes, E.C. (1962) 'Good People and Dirty Work’, Social Problems, 10/1, 3-11. http://dx.doi.org/10.1525/sp.1962.10.1.03a00010

[19] Jewkes, Y. (2011) Media and Crime, London: Sage.

[20] Kelly, T. (2005) 'Mental health and prospective police professionals', Policing: An International Journal of Police Strategies \& Management, 28(1), 6 - 29. http://dx.doi.org/10.1108/13639510510580959

[21] Kennedy-Martin, T. and Prior, A. (Creators) [1962 - 1978] Z Cars, BBC TV.

[22] Kennedy-Martin, T. (1975-1978) The Sweeney, Euston Films.

[23] Kirschmann, E (2000): I Love a Cop: What Police Families Need to Know, New York; The Guildford Press.

[24] Leishman, F. and Mason, P. (2003) Policing and the Media: Facts, Fictions and Factions, Cullompton: Willan Publishing.

[25] Malasch, C. (1982) Burnout: The Cost of Caring. Prentice Hall, New York. NY.

[26] Mankell, H. (Creator) [2005-2013] Wallander, Yellow Bird. 
[27] McKee, A. (2003) Textual Analysis: a beginner's guide, London: Sage.

[28] McQueen, G. (Creator) [1984-2010] The Bill, Thames TV.

[29] Murphy, R (Director) [2010] Nordic Noir, BBC TV.

[30] Reid, G., Stein, B. and Stiehm, M. (Creators) ]2013-14] The Bridge, Sveridges TV.

[31] Reiner, R. (2000), The Politics of the Police, Oxford: OUP.

[32] Siegel, D. (Director) [1971] Dirty Harry, Warner Bros.

[33] Simon, R. (Creator) [2002-2004] The Wire, HBO.

[34] Sud, V. (Creator) [2011-2014] The Killing, AMC.

[35] Van Djik, T.A. (1993) 'Principles of Cultural Discourse Analysis', Discourse and Society, 4, 249 - 283. http://dx.doi.org/10.1177/0957926593004002006

[36] Violanti, J.M (1996): Police Suicide: Epidemic in Blue, Springfield IL: Charles C. Thomas.

[37] Waddington, P.A.J., (1999) Police (Canteen) Sub-Culture: An Appreciation, British Criminology, 39, 2, Spring, 287309.

[38] Weisinger, H. (1985) The Anger Workout Book, New York, NV: Quill.

[39] Willis, T. (Creator) [1955-1976] Dixon of Dock Green, BBC TV.

[40] Wilsher, J.C. (1992-1994) Between the Lines, BBC TV. 